\title{
2008 GALLERY: IMAGES OF THE YEAR
}

\section{8 年、とつておき画像集}

Nature Vol.456 (854-859)/18/25 December 2008

この画像集では、まるで肉食モンスタ一が合唱しているア二メのようなイ力の吸盤の拡大像から、紫色の毛糸で編み上げた数学的な 立体図形まで、見る者を引きつけてやまない 2008 年の科学画像の中から一部を紹介する。また、口ボットを使って進行中の火星探 査など、重大な科学二ュースのいくつかも振り返る。（取材構成：Emma Marris）

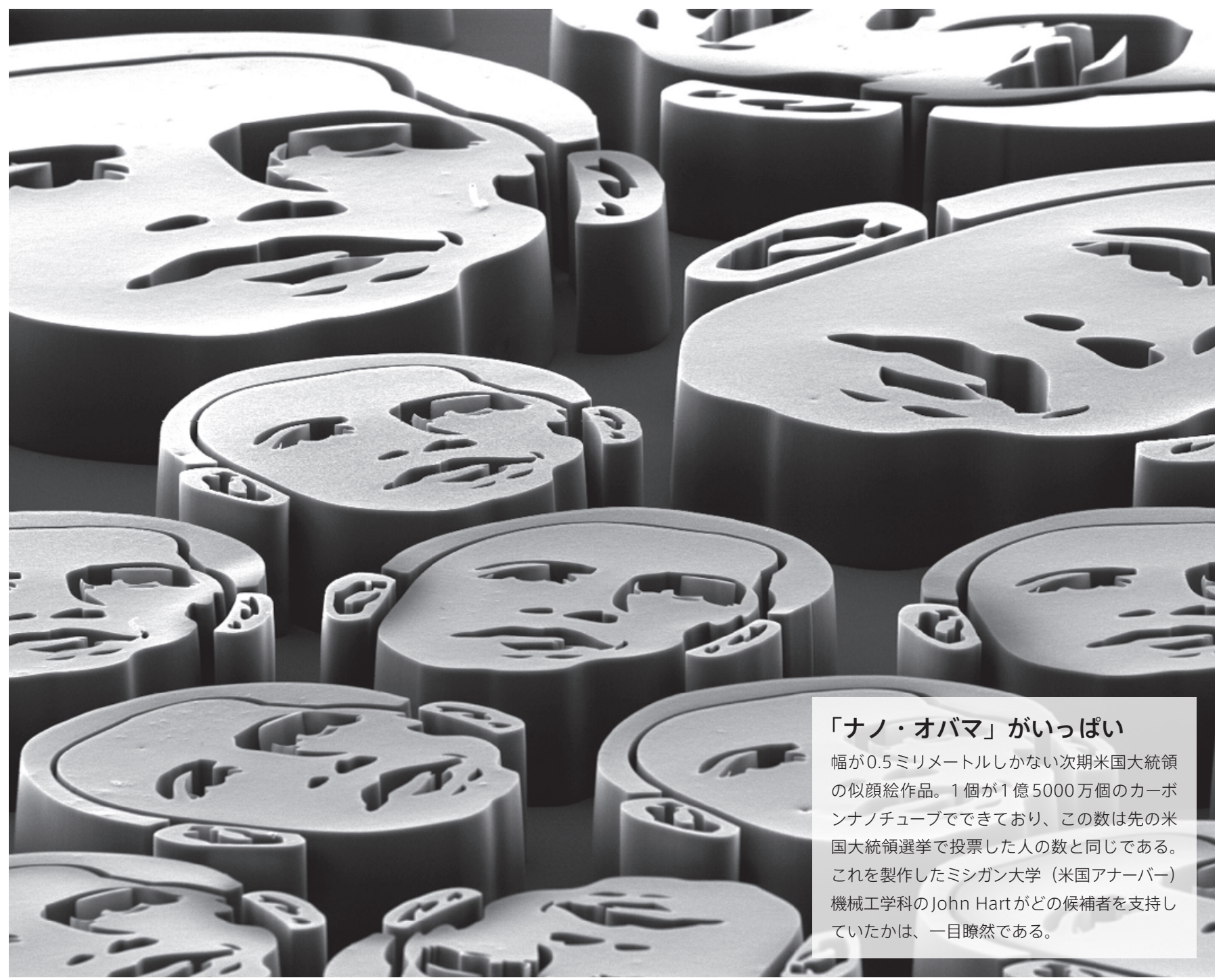




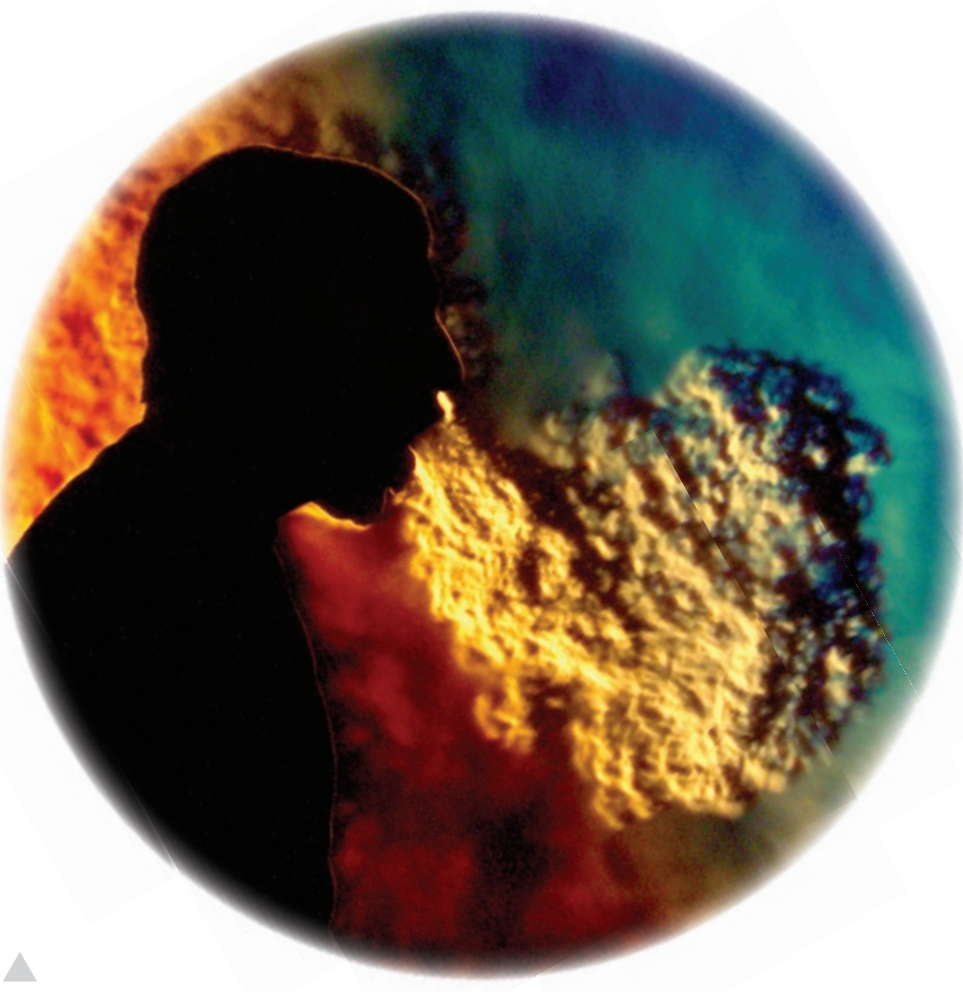

ゴホン！ときたら・・・

米国のペンシルベニア州立大学（ユニバーシティパーク）の気体力学研究所の研究チームは、 空気密度の変化を追跡することで咳を可視化し、咳をするときに口を覆うのがマナーにか なっていることを示す説得力ある証拠を得た。

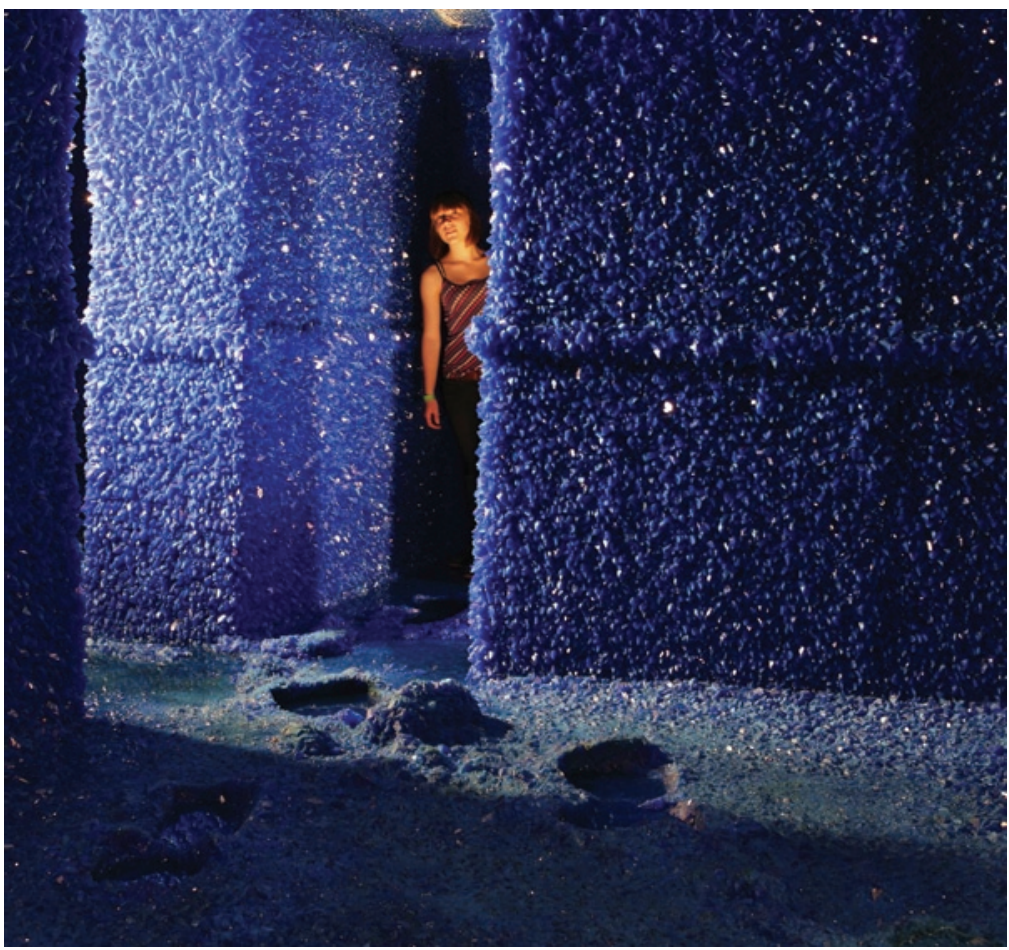

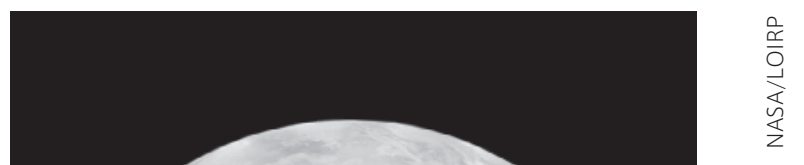

\section{忘れられた最初の「地球の出」}

この画像はもともと1966年にNASAの月周回探査機ル ナ・オービターによって撮影されたもので、アポロ8号の 飛行時に撮影されたシンボル的な「地球の出」の画像よ りも 2 年古い。ルナ・オービターによる画像は、2009年 のルナ・リコネイサンス・オービターの月面地形図作成ミッ ションで得られるデジタル画像と比較できるように、アナ ログデータから再構築されているところである。

\section{結晶に覆われた部屋}

化学が「Seizure」と題する芸術になった。アーティストの Roger Hiornsは助手とともに、ロンドンの廃屋となった集合住 宅の一戸を封鎖し、9万リットルの熱い硫酸銅液でそこを満たし た。硫酸銅液は冷えるにつれて結晶を作り、空間を「青の洞窟」 に変貌させた。 


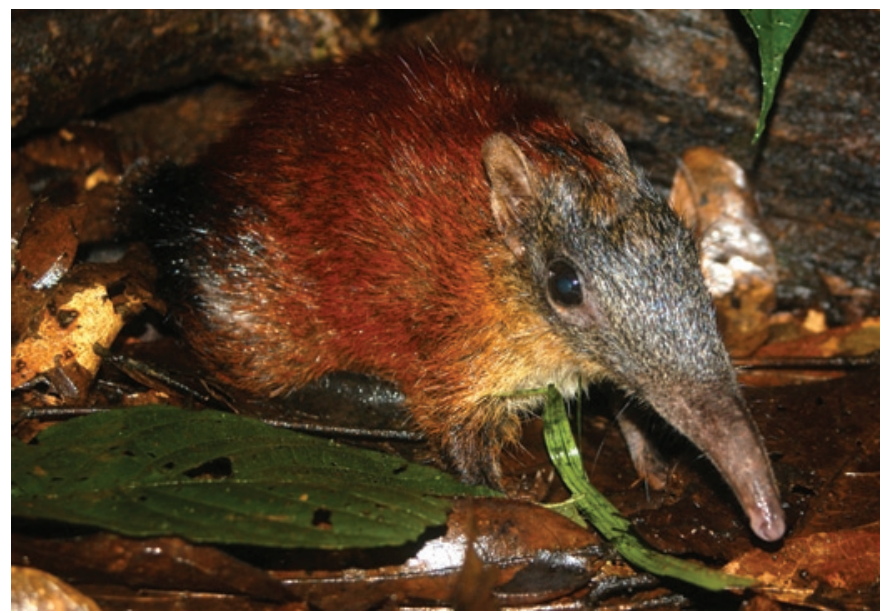

\section{ハネジネズミに初めまして}

タンザニアのウズングワ山脈地帯北部で、研究者グループがハ ネジネズミ（別名ゾウトガリネズミ）の新種を発見した。この 新種はハネジネズミとしては最大サイズとなり、英名を greyfaced sengi、学名をRhynchocyon udzungwensis) と名づけられ、 Journal of Zoologyの 2008年1月号で世界に紹介された。

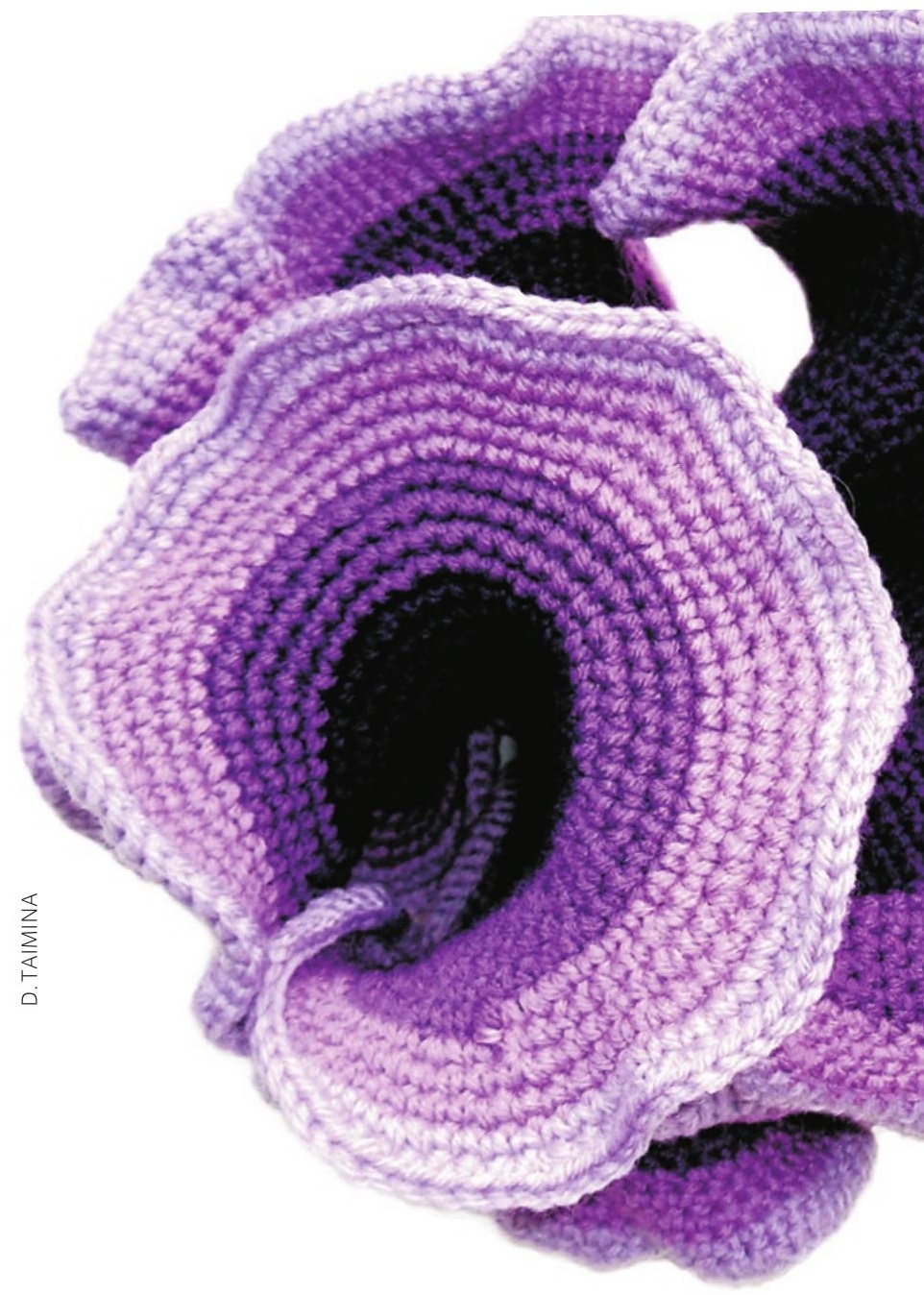

\section{〈太陽系外惑星の撮影に成功}

恒星フォーマルハウトを取り巻く光とちりの中に、小さい点が見 える (白い円の中)。これはフォーマルハウトbと名づけられた惑 星である。2008年11月の時点の見積もりでは、この惑星は地球 から 25 光年離れた位置にあり、質量は木星の 3 倍程度である。 


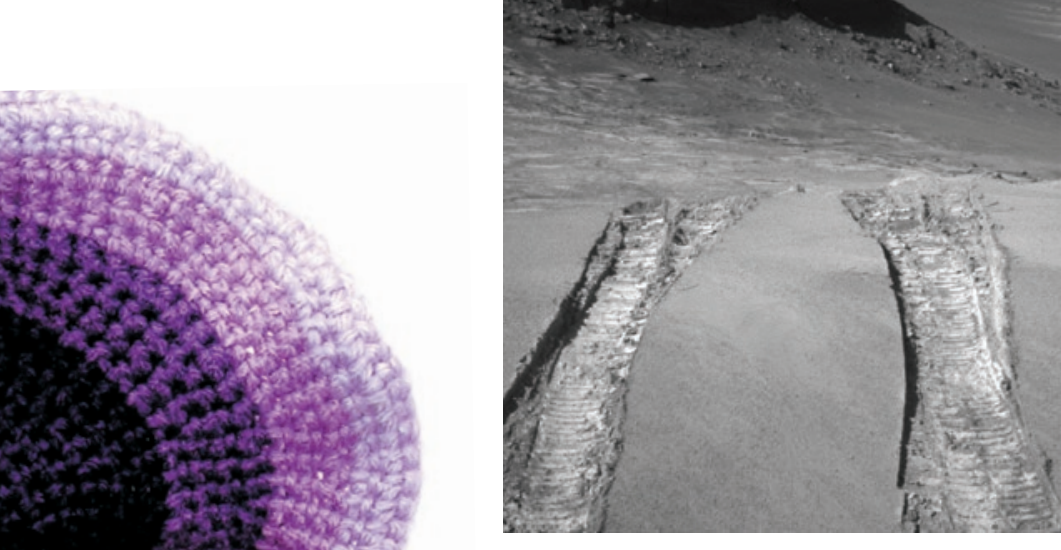

\section{オポチュニティー、脱出に成功}

火星探査機オポチュニティーは、ほぼ1年にわたっ てビクトリア・クレーター内部を調査した後、2008 年8月末にクレーターの外の平地に戻った。画像は そのとき地面に残った「わだち」。

\section{柔らかな手編みのトポロジー}

コーネル大学（米国ニューヨーク州イサカ）の数学者であるDaina Taiminaは、かぎ針で編んだこの双曲平面を、英国ケンブリッジに あるケトルズ・ヤード美術館で開催された『Beyond Measure（測 れないほど)』展に出品した。

\section{ナノ世界の派手な装い}

この彩色された走査電子顕微鏡像は、カーボン繊維の表面に酸化亜鉛製 のナノワイヤーを成長させたもので、ナノワイヤー付きカーボン繊維 1 本の幅は約10マイクロメートルである。大学院生 Sharvari Dalalの手 によるこの画像は、英国ケンブリッジ大学工学部が毎年開催する写真コ ンテストの 2008 年度の参加作品である。

$\checkmark$

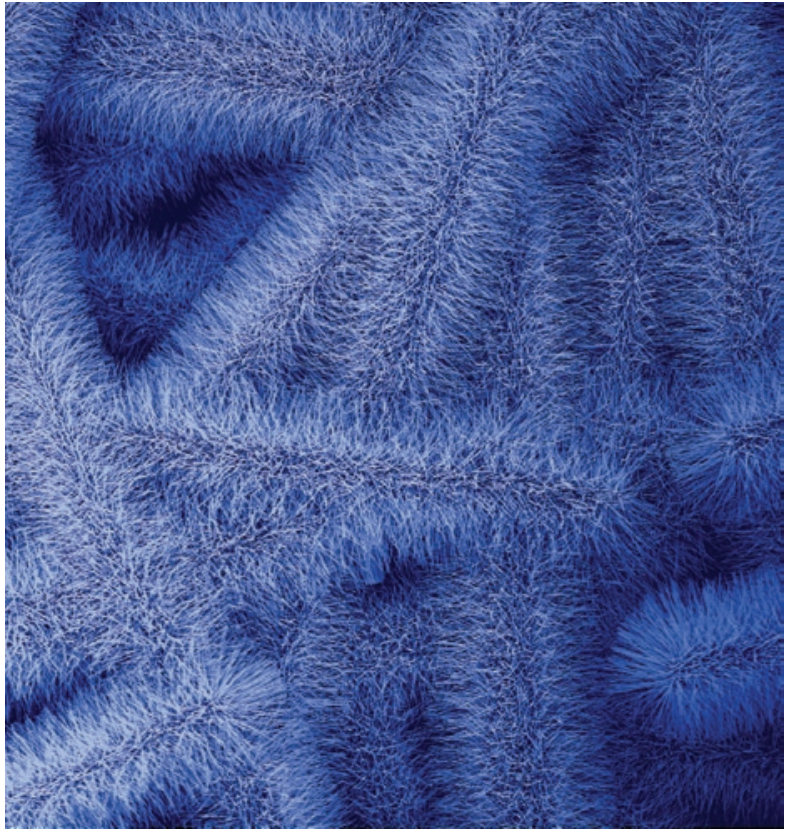

\section{天の川との出会い}

これは、スピッツアー赤外線宇宙望遠鏡で捕らえた我々の銀河系の長大 な画像の一部である。最大解像度でのフルサイズ画像は全長 $60 x-ト$ ルで、80万コマから成り、2008年6月にミズーリ州セントルイスで開 催された米国天文学会総会がデビューの場となった。

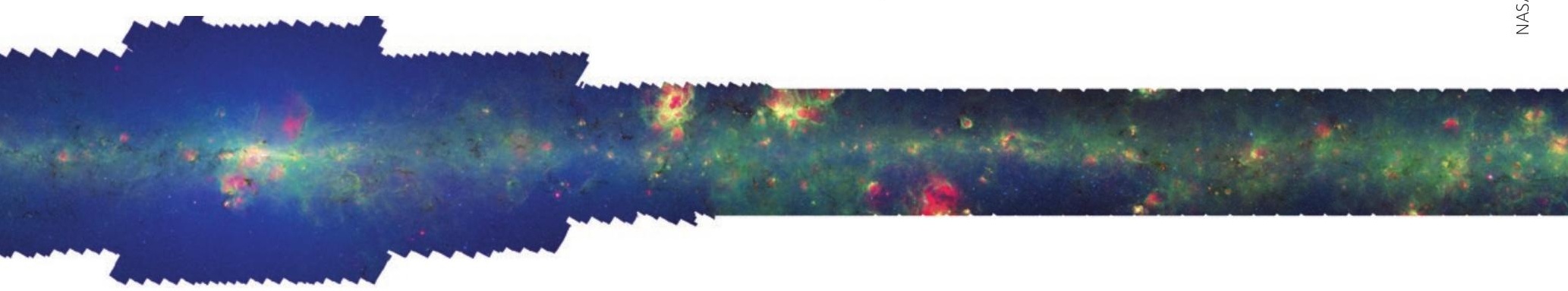




\section{ホラータッチのイカの吸盤}

この電子顕微鏡写真でイカの吸盤の各部分をどん な色に塗ろうかと考えたとき、ドレクセル大学 (米 国ペンシルベニア州フィラデルフィア）のJessica Schiffmanの脳裏には映画の『リトル・ショップ. オブ・ホラーズ』が浮かんだ。その結果できあがっ た画像は、2008年のコンテスト「International Science and Engineering Visualization Challenge」で選外佳作に入った。 $\checkmark$

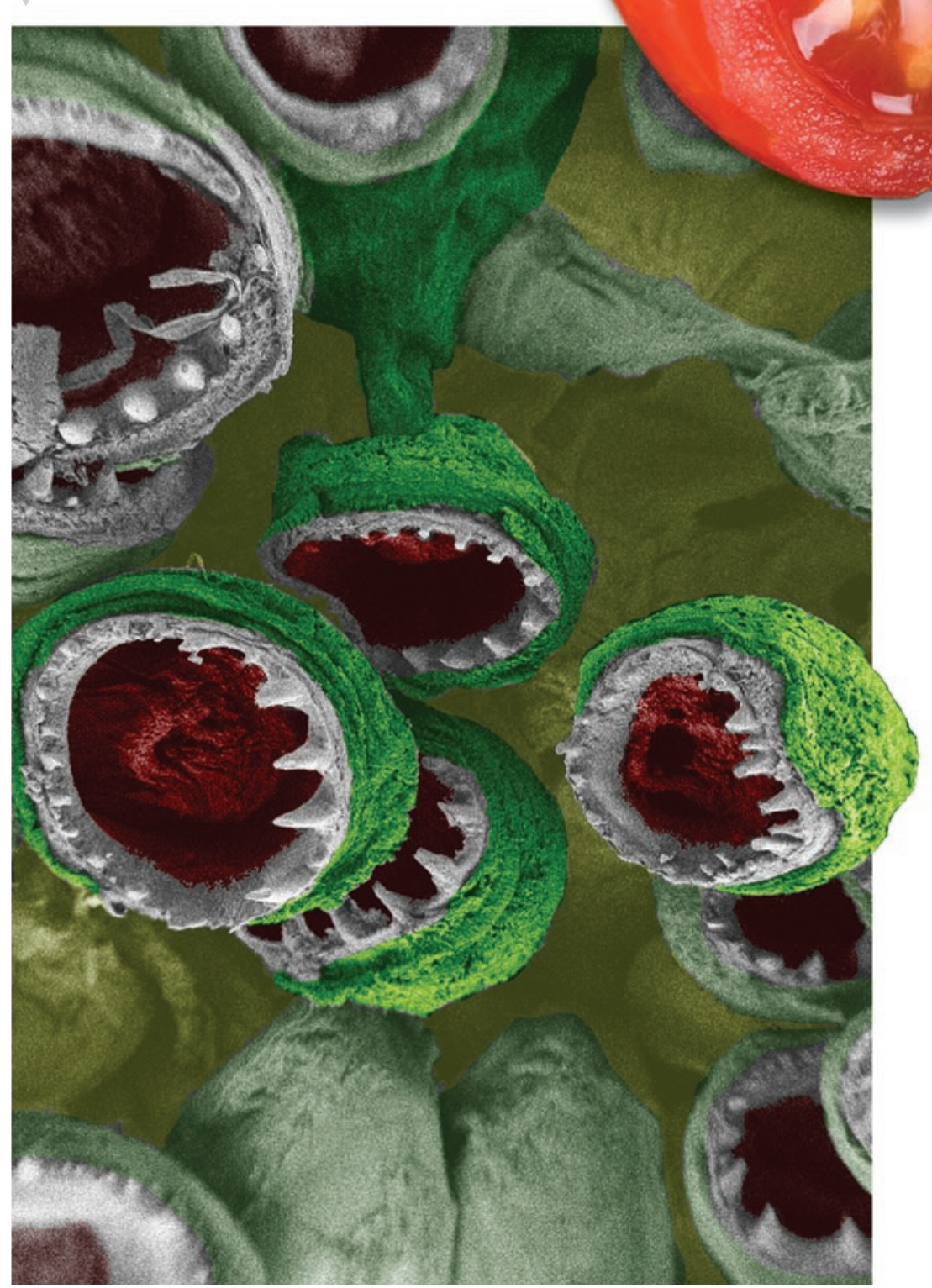

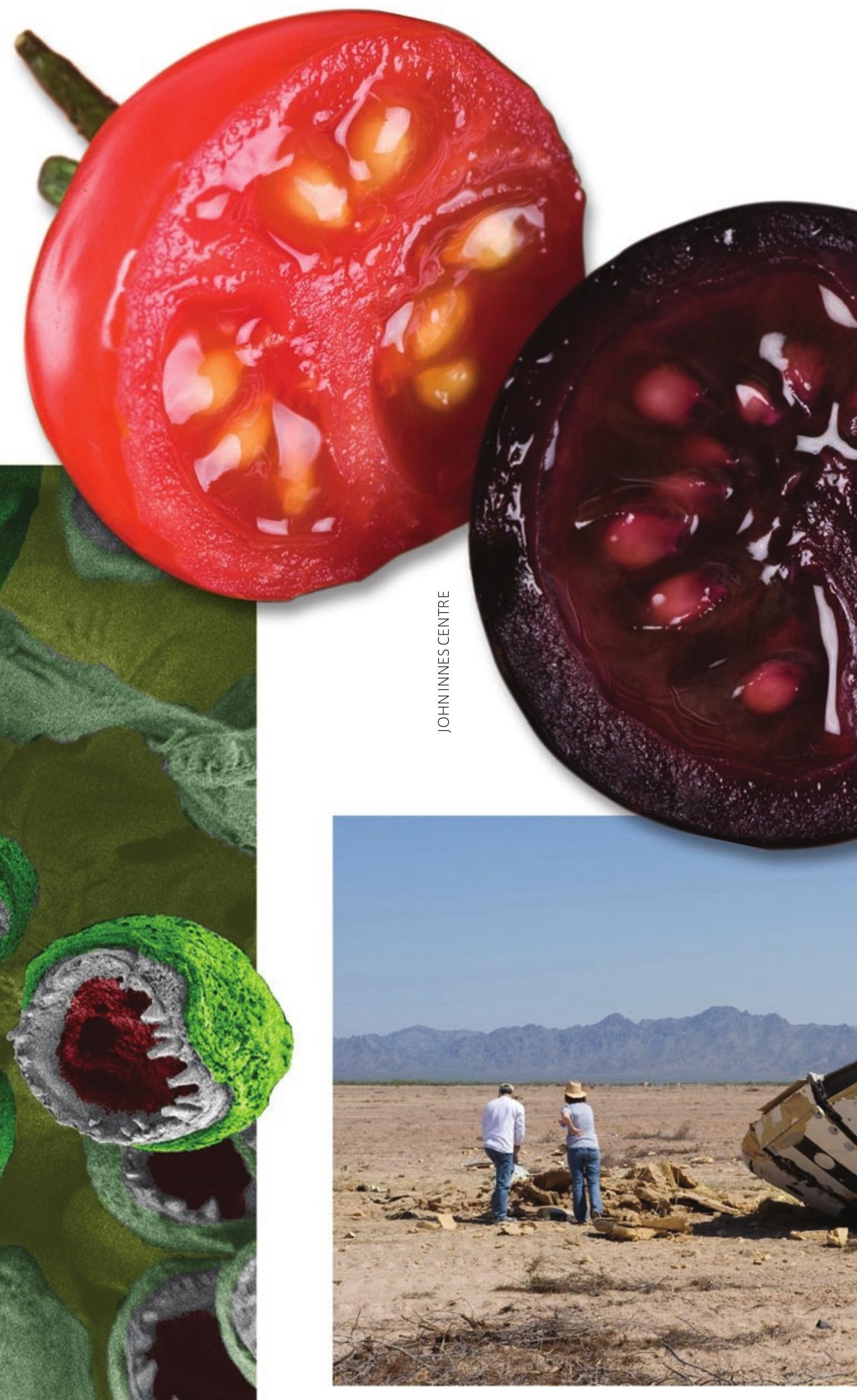




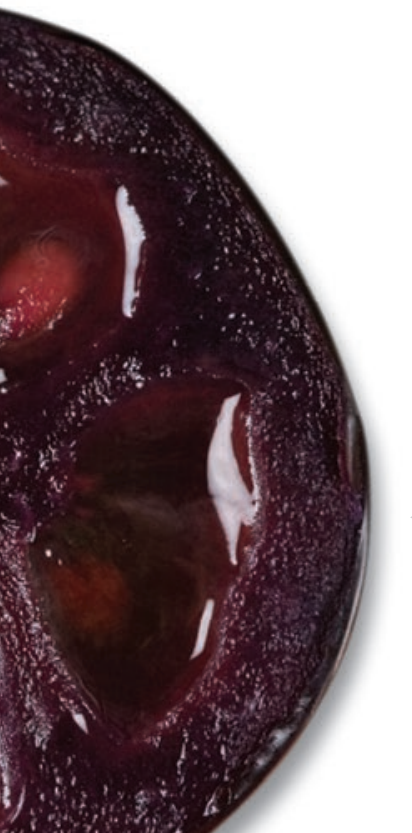

\section{うつろな心}

写真上のラットの心臓は、赤色で見るからに肉の 塊である。写真下の心臟は洗浄剂ですべての細胞 を取り去ってあり、コラーゲンと細胞外マトリッ クスの破片しか残っていない。ミネソタ大学（米 国ミネアポリス）の生物工学者チームによれば、 この構造はいずれ人工心臟を作るための骨組みに 使えるだろうという。

\section{近未来のトマト}

普通のサラダ用トマトにキンギョソウの 2 種類の 遺伝子を導入すると、アントシアニンの豊富な濃 い紫色のトマトになり、これは少なくとも、がん になりやすいマウスにとっては寿命延長効果が あったと、ジョン・イネス・センター（英国ノリッ ジ）の「トマト遺伝子の使い手」であるCathie Martinは話している。
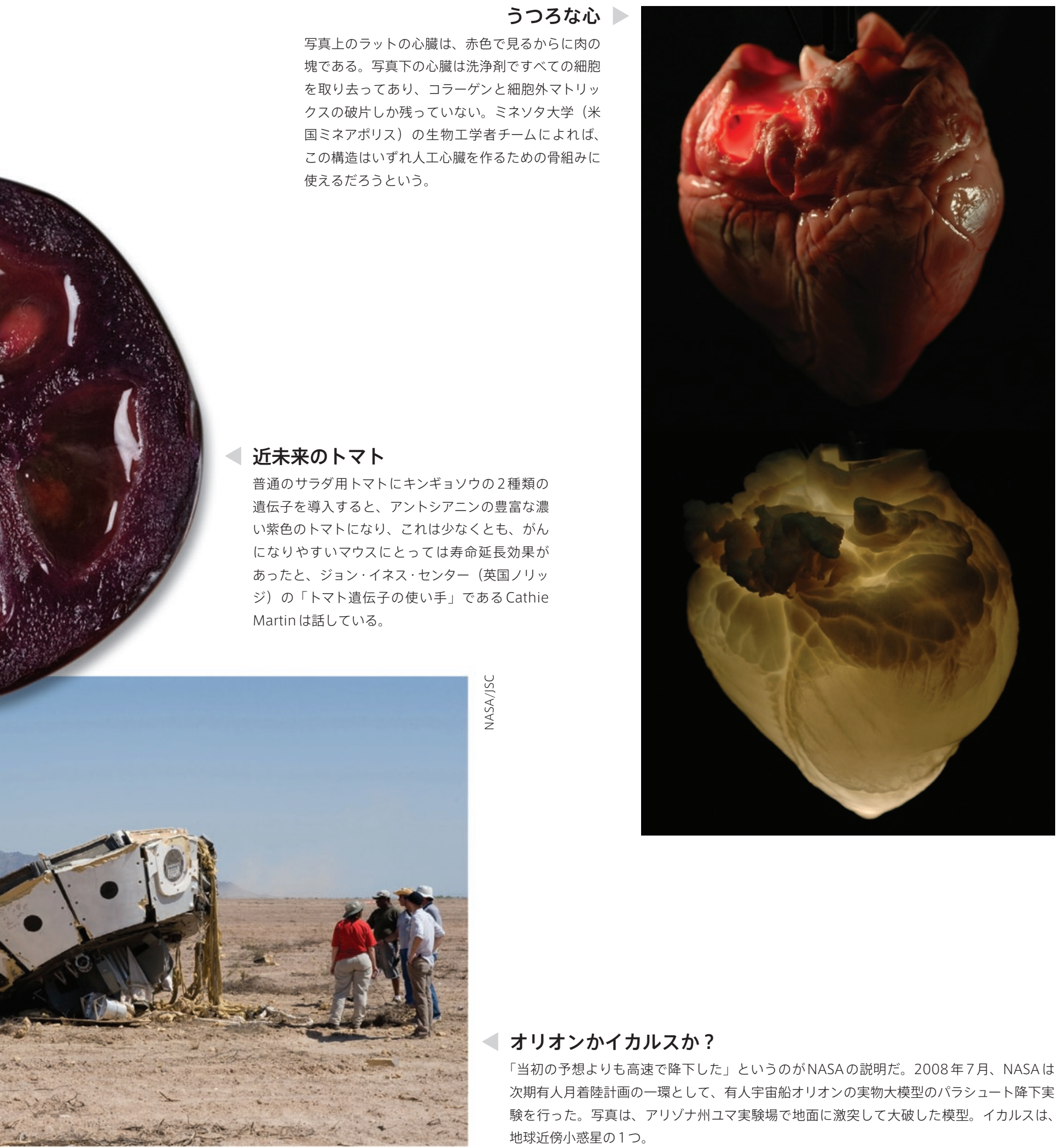

\section{オ オリオンかイカルスか ?}

「当初の予想よりも高速で降下した」というのがNASAの説明だ。2008年7月、NASA は 次期有人月着陸計画の一環として、有人宇宙船オリオンの実物大模型のパラシュート降下実 験を行った。写真は、アリゾナ州ユマ実験場で地面に激突して大破した模型。イカルスは、 地球近傍小惑星の 1 つ。 